$631.445 .4(477.83 / 86)$

\author{
. піші, - озняк \\ ьвівський н ціон льний університет імені в н \\ вул. . орошенк , 41, м. ьвів, 79000, кр їн
}

озглянуто проблеми генези і кл сифік ції чорноземів личини в руслі з г льної теорії еволюції чорноземів лісостепової зони кр їни. грунтово-бот нічних умов $\mathrm{x}$ хідного ісостепу кр їни х р ктер і н прям пізньоголоценової еволюції чорноземів є різним.

лючові слов : чорноземи, феоземи, грунтовий покрив, личин , еволюція грунтів, кл сифік ція, грунтовий горизонт, морфологічні озн ки.

кр їнський етнічний нкл в н з ході д вньоруської держ ви иївськ усь у пізньому середньовіччі зг д ний як ервон усь, пї держ вне утворення - як лицькоолинське князівство. сторичні події після монгольської доби призвели до того, що 3 1340 р. личин розвив л ся як єдиний дміністр тивний регіон у скл ді ечі осполитої, пізніше - встро- горської імперії. ісля третього поділу ольщі 1795 р. історичні г лицькі землі і ч стин олині війшли до встрійської імперії у р нзі “коронного кр ю” з титулом королівств личини і олодимирії. встрійський уряд приєдн в до личини й ч стину польських етнічних земель з центром у р кові. евідповідність дміністр тивної личини історичній, т кож етнічній укр їнській території ст л причиною умовного поділу кр ю н з хідну (польську) і східну (укр їнську) личину, суч сн н зв якої поширюється лише н укр їнський культурно-політичний кр й [4]. огляду н ці обст вини об'єктом н шого н укового н лізу є чорноземи Східної личини.

сторія дослідження чорноземів личини сяг є кінця -поч тку ст. дним 3 перших дослідників у цій г лузі був встрійський учений . убер, який 1910 р. опублікув в німецькою мовою моногр фію “ ро чорноземи ліції і одоліі”. втор повно й об'єктивно висвітлив погляди б г тьох учених, почин ючи 3 . омоносов , н походження чорноземів. ирокому з г лу укр їнських і німецьких грунтозн вців н укові пр ці. убер в г лузі дослідження чорноземів личини пр ктично невідомі.

“ стории почвоведения” . рупеніков зг д в про доробок цього вченого, який першим дослідив чорноземи г лицького кр ю [7]. езв ж ючи н зн чний ч совий відрізок 3 моменту появи перших ф ктичних д них про чорноземи кр ю, з усіх провінцій чорноземної зони кр їни чорноземи хідного ісостепу, і передусім личини, вивчені н йсл бше. вдяки великом сшт бним грунтовим дослідженням другої половини ст. м ємо точні уявлення про геогр фію чорноземів личини, особливості їхньої морфології, фізичні, хімічні, біологічні й гровиробничі вл стивості. роблеми ж генези чорноземів личини висвітлені в з г льному руслі еволюційної теорії генези чорноземів лісостепової зони кр їни без тісної ув'язки їх з ф ці льними особливостями

(C) піш ., озняк ., 2010 
голоценового грунтоутворення в конт ктній зоні між оліською і рп тською широколистяно-лісовими і хідноєвропейською лісостеповою геобот нічними обл стями.

м тері л ми великом сшт бних грунтових досліджень ьвівщини чорноземи в г лицькому прикордонні приурочені винятково до янсько- ністерської моренно-воднольодовиково- люві льної хвилястої сл бкорозчленов ної височини, з хідні відроги якої не з ходять н територію ольщі.

фізико-геогр фічним р йонув нням кр їни історичн личин сформув л сь у меж х грунтово-біоклім тичної провінції ісостепу хідного ісостепової зони кр їн, скл довими ч стин ми якого є п'ять грунтово-бот нічних округів: ерхньодністерський і озтоцько- пільський листянолісовий рівнинний округ сірих лісових грунтів і чорноземів опідзолених, хідноподільський, хідноподільський, ридністерсько-

одільський і рут- ністерський лісостепові рівнинні округи чорноземів опідзолених і типових з остров ми сірих лісових грунтів [3].

структурі грунтового покриву личини чорноземи предст влені двом ф ці льними підтип ми: чорнозем ми опідзоленими і типовими вологими. оширені вони вкр й нерівномірно, утворюючи перев жно скл дні висотновпорядков ні поєдн ння 3 сірими лісовими грунт ми, н півгідроморфними і гідроморфними грунт ми. ідносн ч стк чорноземів у грунтовому покриві ерхньодністерського і озтоцько- пільського грунтово-бот нічних округів незн чн і диференційов но збільшується у східному н прямі від першої до другої з 10-12\% до 18-20\%. грунтовому покриві цих лісових обл стей лицького кр ю чорноземи предст влені винятково опідзоленим підтипом.

меж $\mathrm{x}$ ерхньодністерського грунтово-бот нічного округу чорноземи опідзолені приурочені до широких сл бкорозчленов них вододільних м сивів, довгих і пологих привододільних схилів янсько- ністерської і ородоцько- ом рнівської височин. грунтовому покриві округу вони утворюють вузький, розчленов ний боковими відрог ми сірих і темно-сірих лісових грунтів субширотний м сив чорноземів, що витягнулись н десятки кілометрів уздовж південного м кросхилу височин. верхів'ях p. ишні глибоко і густо розчленов н удківськ височин перерив є суцільність м сиву чорноземів ун слідок бсолютного домінув ння в грунтовому покриві цієї височини сірих лісових грунтів. онолітність ре лу чорноземів відновлюється тільки зі зміною х р ктеру рельєфу і скл ду грунтотвірних порід у межиріччі ишня - ерещиця ородоцько- ом рнівської горбистої пологохвилястої сл бкорозчленов ної височини. е р йон м ксим льно комп ктного поширення чорноземів у меж х ерхньодністерського грунтово-бот нічного округу.

умов озтоцько- пільських л ндш фтів чорноземи опідзолені м ють перев жно острівне поширення, зумовлене х р ктером рельєфу і літологією грунтотвірних порід.

межиріччі ерещиці т убри сформув лись дв зн чні ре ли чорноземів опідзолених. ерший приурочений до північних відрогів ерозійно- кумулятивної структурнопл стової рівнини ьвівського пл то з його широкими мікроз п динними (к рст) вододільними поверхнями, що скл дені оглеєними елюві льно-делюві льними лесоподібними суглинк ми в основі. руг комп ктн груп чорноземів опідзолених приурочен в рельєфі до пологохвилястої ирецької сідловини верхньотортонського гіпсоносного м сиву, перекритого м лопотужною товщею оглеєних елюві льно-делюві льних лесоподібних суглинків. ерез особливості д вньої тектонічної структури, дочетвертинної геології і новітні грунтово-геоморфологічні процеси (к рстоутворення, оглеєння) в околицях злиття річок т вч нки і ирки скл лись сприятливі умови для голоценового чорноземоутворення під покривом широколистих лісів дібровного типу. д фічні умо- 
ви середнього і пізнього голоцену ьвівського пілля н пологохвилятих перезволожених рівнин х сприяли поширенню дібров п ркового типу з чорнозем ми опідзоленими. н логічний $\mathrm{x}$ р ктер рельєфу пілля не єдиний і дост тній чинник у формув нні чорноземних грунтів. прикл д, грунтовий покрив н пологохвилястому межиріччі у виток х ерещиці і т вч нки ( еликолюбінськ синекліз ) скл дений винятково світло-сірими і сірими лісовими грунт ми. цьому вип дку просторовий х $\mathrm{p}$ ктер i скл д грунтового покриву визн чив літологічний чинник. рунтотвірні породи предст влені прісноводними воднольодовиково- люві льними облесов ними оглеєними суглинк ми легкого гр нулометричного скл ду. овсюди, де породи цієї генези є грунтотвірними, нем ре лів чорноземних грунтів.

одібн 3 кономірність спостережен в однотипних літологічних умов х розчленов них межиріч з елюві льно-делюві льними лесоподібними суглинк ми, проте з посиленням вертик льного і горизонт льного ерозійного розчленув ння території пілля. ериторії, скл дені елюві льно-делюві льними лесоподібними суглинк ми, в р зі посилення ерозійного розчленув ння території перев жно з йняті темно-сірими, менше - сірими лісовими грунт ми. м сив х сильнорозчленов ного рельєфу, скл деного 3 поверхні прісноводними верхньоплейстоценовими суглинк ми, сформув лися світлосірі лісові грунти. орелятивні зв'язки між х р ктером структури грунтового покриву ьвівського пілля і чинник ми його просторової диференці ції свідч ть про те, що н йсприятливіші умови для голоценового чорноземоутворення в меж х лісового м сиву ьвівського пілля скл лись н перезволожених територіях з поєдн ння пологохвилястого рельєфу, предст вленого у верхньому стр тигр фічному ярусі еоловими елюві льно-делюві льними лесоподібними суглинк ми.

середньом сшт бній грунтовій к рті кр їни чорноземи опідзолені ерхньодністерського і озтоцько- пільського листянолісових грунтово-бот нічних округів хідного ісостепу кр їни зобр жені як поверхнево-глеюв ті. ей ф кт вир зно х р ктеризує ре льні обст вини пізньоголоценового грунтоутворення н 3 ході г лицького кр ю, одн к не достовірно відтворений у кл сифік ції чорноземів н грунтовій к рті кр їни. орноземи опідзолені в б сейні лівих приток верхнього ністр , ж до долини p. убр, протягом голоцену формув лись у досить скл дних геолого-геоморфологічних (передовий к рп тський прогин з інверсійним структурно-пл стовим типом рельєфу і бсолютними відмітк ми земної поверхні 150-200 м) і біоклім тичних (лісовий тип рослинності при > 1,7) умов х середнього лісостепу [2]. верді дочетвертинні породи (пісковики, в пняки, піски, гіпси й гіпсо нгідрити), н явність під грунтовим профілем пізньоплейстоценового сильно оглеєного, пл стичного і водонепроникного діяльного ш ру (1 м) дубнівського інтерст ді лу, т кож зн чне обводнення території спричинили високий рівень стояння грунтових вод, підтоплення чорноземів к пілярною облямівкою з утворенням моч рів н вододіл х і схил х.

умов х ьвівського пл то чорноземи опідзолені вододільних поверхонь утворюють х р ктерні для цього регіону н півгідроморфні грунтові комплекси з лучно-чорноземними, лучно-болотними і болотними грунт ми к рстових блюдець і міжк рстових поверхонь. езонне підтоплення чорноземів (рівень з ляг ння грунтових вод н вододіл х ч сто піднім ється до 80-180 см) стимулює формув ння потужного (50-60 см) оглеєного кумулятивно-гумусового горизонту, який поступово переходить у сл бкодиференційов ну з гр нулометричним і в ловим хімічним скл дом гідрогенно-мет морфізов ну товщу. ет морфізм ч сто виявляється в н явності глейового горизонту в нижній ч стині профілю, мет левому блиску й оливкових озн к х оглеєння перехідного 
гумусового горизонту, дрібних ірж вих конкреціях сполук з ліз в гумусовому горизонті, сильних н тік х орг нічної речовини (н віть глибоко в м теринській породі). рунтов м с перехідних горизонтів брудно-бурого кольору, ч сто горіхув то-грудкув т з сизо-сірими плівк ми по гр нях структурних грег тів, як вир зно переходить у тверду і пл стичну, брилув то-блокової структури м теринську породу. $\mathrm{k}$ морфологія профілю чорноземів опідзолених ьвівського пілля не відповід є їхньому кл сифік ційному визн ченню як поверхнево-глеюв тих опідзолених чорноземів. одібн будов профілю вл стив опідзоленим чорнозем м ерхньодністерського лісостепу, що пок з ні н грунтовій к рті кр їни т кож як поверхнево-глеюв ті.

оверхнев глеюв тість чорноземів середнього хідного ісостепу у більшості вип дків не м є польових підтверджень. ктично місце цих грунтів у систем тичному списку грунтів кр їни не відповід є їхньому ре льному положенню в структурі грунтового покриву кр ю, оскільки озн ки оглеєння поширені в усьому профілі чорноземів, причому посилюються з глибиною. евідповідність родової оцінки чорноземів середнього хідного ісостепу (н явність поверхневої глеюв тості) не обмежен тільки цією обст виною. явність рясної крем'янкової присипки н гр нях педів і в тріщин х грунтових блоків помилково вв ж ють результ том пізньоголоценового опідзолення чорноземів типових глибоких. ілув т скелет н швидше $є$ озн кою псевдопідзолистого процесу в умов х трив лого поверхневого і грунтового перезволоження чорноземів у ділянці к пілярної облямівки. ідсутність між гумусово-елюві льним генетичним горизонтом $e(g l)$ і перехідним гумусовим горизонтом $i g l$ пізньо тл нтичного кумулятивно-гумусового горизонту є непрямим свідченням відсутності явищ п р метоморфозу цих чорноземів з умов зміни степової рослинності н лісову. “ л сифік ції і ді гностиці грунтів " т кі грунти більше відповід ють підтипу дерновоглеюв тих грунтів з типу дерново-глейових, ч стково - типу лучних вилугув них грунтів. л сифік ції грунтів осії грунт м з т кими морфохром тичними вл стивостями профілю виділили, н н шу думку, об'єктивну нішу. они н леж ть до окремого відділу ( соці ції грунтів) кумулятивно-гумусових гідрогеннотр нсформов них грунтів і до типу гумусово-глейових [6].

орноземи з морфохром тичними озн к ми псевдоопідзолення і повнопрофільного оглеєння поширені н всьому просторі ерхньодністерського і озтоцько- пільського лісостепу. они є специфічним і невип дковим явищем у грунтовому покриві регіону, зумовленим історією розвитку природи цього кр ю н межі між лісом і степом. ояв т ких грунтів с ме н простор х хідної личини свідчить про їхнє перехідне положення між чорнозем ми кл сично лісостепових л ндш фтів і лісо-лучними грунт ми центр льноєвропейської широколистолісової обл сті. е грунти лісової генези, що сформув лись у специфічних ед фічних умов х перехідного поясу хідного ісостепу кр їни в конт ктній зоні буроземного, підзолистого і степового поясів грунтоутворення. кі грунти повинні посісти особливе місце в систем тиці і кл сифік ції грунтів кр їни, яке відповід ло б їхнім ре льним субст нтивним озн к м і вл стивостям. н шу думку, у кл сифік ції грунтів кр їни вони можуть бути з числені до соці ції кумулятивно-гумусових грунтів з утворенням окремого типу феоземів глейових. рівні підтипів виділяються феоземи глейові типові т феоземи перегнійно-глейові. умов х грол ндш фтів виділяють грофеоземи глейові з відповідним підтиповим поділом.

схід від р. убр історичн личин є обл стю підвищеного ( бсолютні відмітки -360-400 м) хідного ісостепу, як умовно розділен н 3 хідну і східну його ч сти- 
ни [5]. е обл сть поширення лісостепових чорноземів опідзолених і типових, що є продовженням обл сті сірих лісових грунтів н схід від 25-го мериді н до р. бруч.

p вобережному дністер'ї обл сть лісостепових чорноземів опідзолених і типових поширюється н рут- ністерське межиріччя. лісостепових, 3 геобот нічного погляду, грунтово-бот нічних обл стях личини чорноземи є домінуючим типом грунту. ричому в структурі грунтового покриву ч стк типових чорноземів щодо опідзолених стрімко збільшується в н прямі бруч і ністр . тому ж н прямі зменшується гідроморфність чорноземів вологих.

орноземи з хідної ч стини підвищеного поясу хідного ісостепу кр їни охоплюють ерозійно-денуд ційні рівнини ологоро- ременецького н півгірського кр ю оділля і розчленов ного хідного пілля. цій ч стині підвищеного лісостепу чорноземи предст влені підтипом опідзолених глеюв тих і поверхнево-глеюв тих грунтів. ісовий тип рослинності в історичному минулому у поєдн нні з високим тмосферним зволоженням н фоні доброго дрен жу території створює передумови до н длишкового поверхневого зволоження грунтів. е ліз ція цих передумов з лежить від рослинного покриву, геологічної будови і рельєфу, скл ду грунтотвірних порід і вл стивостей с мих грунтів. орноземи опідзолені сформув лись під дібров ми з потужним н земним тр в'яним покривом. віть під цими ліс ми чорноземи швидко н гром джують у верхньому ш рі (0-10 см) 6 г то орг нічної речовини, як 3 огляду н місцеві клім тичні умови і високу вологоємність сприяє н дмірному зволоженню і поверхневому оглеєнню грунтів.

орноземи опідзолені підвищеного поясу хідного ісостепу кр їни суттєво відрізняються від своїх н логів ереднього ісостепу. орфохром тичні озн ки оглеєння в них посл блюються з глибиною. рунтовий профіль - це поступовий перехід гумусово- кумулятивного горизонту $e$ через сл бкоілювійов ний зернисто-горіхув тий перехідний гумусовий горизонт $i$ в к рбон тну (зрідк безк рбон тну н прісноводних суглинк х) грунтотвірну породу з озн к ми реліктового гігроморфізму. орфохром тичних озн к процесів м рмуриз ції, зумовлених псевдоопідзоленням і оглеєнням, у середній і нижній ч стин х профілю нем . ідгумусову товщу х р ктеризують поступовий сп д гумусності, н дмірн ущільненість, тріщинув тість, грудкув то-горіхув т структур , нем є озн к глибокого проникнення орг нічної речовини в м теринську породу. оверхневий оглеєний, білястий, пл стинч сто-грудкув тий гумусово-елюві льний горизонт $e$ поступово переходить у зернисто-грудкув тий горизонт без вир зних озн к опідзолення, д лі - у перехідний сл бкоілювійов ний гумусовий горизонт

$i$ без озн к криптоглеюв тості. к будов профілю чорнозему свідчить про його скл дну генезу вн слідок з селення лісом чорнозему глибокого в минулому і н ступного суб тл нтичного опідзолюв ння його верхнього ш ру. цьому вип дку чорноземи підвищеного хідного ісостепу з морфохром тичними озн к ми і вл стивостями відповід ють їхньому кл сифік ційному положенню, з фіксов ному н середньом сшт бній грунтовій к рті кр їни. руслі розвитку кл сифік ційної проблеми ці грунти потрібно з числюв ти до типу феоземів, що входять до соці ції кумулятивногумусових грунтів. особливостями серединного типоді гностичного горизонту в типі феоземів виділяють підтипи: феоземи типові (чорноземи опідзолені в кл сифік ції грунтів 1977 р.), феоземи лювікові (чорноземи вилугув ні), феоземи опідзолені (темносірі опідзолені грунти), феоземи глеюв ті (лучно-чорноземні грунти). умов х грол ндш фтів типу феоземів відповід є окультурений їх н лог - грофеоземи. 
грунтовому покриві східної ч стини підвищеного хідного ісостепу домінують поєдн ння чорноземів опідзолених і типових м логумусних глеюв тих. ре ли їхнього поширення простяг ються від вододілу між річк ми трип i оропець н 3 ході, до бруч i руту, відповідно, н сході і півдні личини. цих меж х підвищений типовий ісостеп охоплює лесову структурно-пл стову рівнину із з г льним н хилом земної поверхні н схід-південний схід, що розділен овтровим п смом н хідноподільську ( ернопільське пл то) і хідноподільську ( вр тинськ височин ) ч стини. омінув ння в грунтовому покриві чорноземів типових зумовлене плоско-хвилястим сл бкодренов ним рельєфом, скл деним з поверхні еоловими елюві льно-делюві льними, з озн к ми реліктової глеюв тості, лесоподібними суглинк ми, т кож посиленням континент льності клім ту в східному н прямі. ерехід від чорноземів опідзолених до типових відбув ється поступово із з ходу н схід з посиленням пенепленіз ції рельєфу. йбільші м сиви типових глибоких чорноземів зосереджені у межиріччі ерету і бруч . ме т м, в урочищі нтелих ( еребовлянський р-н ернопільської обл.) з лишились невеликі м сиви цілинних глибоких чорноземів зістеповілих лук.

p ктерною особливістю чорноземів типових ернопільського пл то і вр тинської височини є їхня глибок й інтенсивн зоогенн переритість профілю, вн слідок чого перехідний гумусовий горизонт дуже розтягнутий, гетерогенний і кротовинний. еред н логів лісостепової зони кр їни чорноземи типові личини вирізняються н йбільш диференційов ним 3 мулом грунтовим профілем ( мулу 1,26-1,28), розвитком процесів внутрішньогрунтового оглинення в перехідних з гумусом горизонт х профілю ( огл 1,2-1,38), н йбільш розтягнутим гумусовим профілем з вдяки зоогенній переритості перехідного гумусового горизонту, високій розсіяності к рбон тних новоутворень у профілі, вир женому елюві льно-мет морфічному типу профілю, м логумусності кумулятивно-гумусового горизонту, високому ступені гуміфік ції орг нічної речовини. рунти відповідної генези й будови профілю однозн чно м ють н леж ти до типу чорноземів, що входять до соці ції кумулятивно-гумусових грунтів. підтиповому рівні в меж х личини потрібно виділити підтип чорноземів типових. культурені н логи чорноземів типових формуються шляхом дод в ння до них префікс гро- ( грочорноземи типові).

орноземи, як і більшість грунтів боре льних обл стей, формув лись протягом усього голоцену. явлення про голоценову еволюцію чорноземів личини вкр й дискусійні. они неоднозн чні в тр ктув нні генези грунтів, послідовності ст дій і ет пів їхнього розвитку й еволюції, впливу господ рської діяльності н формув ння вл стивостей чорноземів. искусій щодо еволюції чорноземів типових не виник є. они є моногенетичними грунт ми, що у суч сному ст новленні пройшли кільк ф з степового грунтоутворення. кожній зі ст дій вони еволюціонув ли з розвив льним типом н елюві льно-делюві льних к рбон тних лесоподібних суглинк х під гігрофільною лучною і мезофільною лучно-степовою рослинністю.

о-іншому скл лись історичні обст вини з чорнозем ми опідзоленими вологими. еред виріш льних чинників і умов еволюції чорноземів лісових грунтово-бот нічних обл стей личини є х р ктер рельєфу, особливості грунтотвірної породи і біоклім тичний чинник. ісостеп як с мостійн природн зон дуже стійкий щодо клім тичних колив нь, що зумовлено диференційов ним рослинним покривом. гідно з п лінологічними д ними і р діовуглецевим д тув нням, до кінця тл нтичного періоду (5-6 тис. років тому) меж між лісом і степом, тобто північн меж лісостепу, досягл положення, близького до суч сного. д лі вон не з зн в л суттєвих переміщень [10]. 
суч сних вторитетних вид ннях опідзолені чорноземи личини розгляд ють як полігенетичні грунти, що сформув лись ун слідок суб тл нтичної дегр д ції лучностепових чорноземів під впливом лісової рослинності $[1,2]$. е взяті до ув ги особливості генези чорноземів 3 умов, перехідних від кл сично лісостепових до широколистянолісових центр льноєвропейських. лінологічні дослідження в івденній оp вії з свідчили лісову, не степову генезу середньоєвропейських чорноземів [8]. меж х лісових грунтово-бот нічних обл стей личини, з винятком поодиноких вип дків, не виявлено чорноземів, які протягом середнього і пізнього голоцену розвив ються в умов х степової рослинної форм ції. кби т кі існув ли у минулому, то їхній генетичний профіль зберігся б до сьогоднішнього дня у м йже незміненому вигляді й під дібров ми, що є п нівними рослинними соці ціями б сейну ерхнього ністр i угу 3 середнього голоцену. вдяки високій сенсорності степових чорноземів, подібності пок зників біологічного колообігу речовин у дібров х і лучних степ х (одн ковий об'єм первинної рослинної продукції нез лежно від положення екосистеми в рельєфі), несуттєвими для чорноземів відмінностями хімізму цих колообігів ( зотно-к льцієвий у дібров х т зотно-кремнієво-к льцієвий у лучних степ х) степові чорноземи є екологічно стійкими щодо експ нсії лісів дібровного типу. езн чних змін з зн є тільки к рбон тний профіль.

д ними . лекс ндровського, протягом 2-3 тис. років під покривом лісу може повністю дегр дув ти гумусовий горизонт лучно-степових чорноземів [1]. роведені н ми профільно-генетичні дослідження чорноземів типових під дібров ми ерхньобузької височини д ють дещо іншу к ртину. чорнозем х типових під 6 г товіковою дібровою (про що свідч ть д ні к д стрових книг), н йповніше дегр дув в к рбон тний профіль, зн чно менше - дисперсність перехідного горизонту чорноземів. більшились коефіцієнт диференці ції мулу, відносн ч стк горіхув тих грег тів у структурно- грег тному скл ді грунтів, текучість орг нічної речовини і язикув тість нижньої межі гумусового горизонту. вп ки, гумусність і глибин гумусового профілю зросли порівняно 3 н лог ми н узліссі. кі висновки підтверджені дослідженнями в н логічних умов х південно-з хідних відрогів ередньоруської височини [1]. тже, лучно-степові екосистеми, які в р вобережному і івобережному ісостепу кр їни були типовими екосистем ми протягом середнього і пізнього голоцену, в умов $\mathrm{x}$ личини н 3 хід від 25-го мериді н ст ли скоріше винятком, ніж 3 г льним пр вилом.

ідсутність степової ф зи в еволюції чорноземів опідзолених личини пов'язують т кож зі зн чними колив ннями їхньої гумусності. дному й тому ж ступеню опідзолення чорноземів відповід є різн їхня гумусність. е не узгоджується із твердженнями про дегр д цію гумусності в р зі опідзолення чорноземів. ку невідповідність пояснюють поч тково різною гумусов ністю вихідних чорноземів. роте дослідження . юрін щодо скл ду гумусу опідзолених чорноземів конст тують інше. них нем є озн к “з лишкового" гумусу степових чорноземів. вп ки, простежен н явність суч сного гумусу, генез якого пов'яз н з умов ми суб тл нтичного періоду голоцену. тже, під сумнів ст виться п р генетичність опідзолених чорноземів не тільки личини, й усього ісостепу.

ітологічні особливості чорноземів верхньодністерського й опільського лісових м сивів свідч ть про можливість їхньої еволюції під дерев'янистою рослинною форм цією. ідсутність к рбон тів у лесово-грунтовій товщі і м лопомітн ш рув тість прісноводних верхньоплейстоценових лесоподібних суглинків є озн кою того, що ці поро- 
ди, ймовірно, були перевідкл дені уже в безк рбон тному ст ні [2]. відміну від верхньодністерських чорноземів опідзолених, їхні н логи лісостепових геобот нічних обл стей личини (з суб тл нтичного ч су формуються в подібних екологічних умов х) вирізняються порівняно неглибокою вилугув ністю к рбон тів, меншою глинистоілюві льною диференці цією профілю, більшою біогенною переритістю перехідних горизонтів.

орноземи опідзолені лісових грунтово-бот нічних обл стей личини пройшли три головні ет пи історичних змін грунтоутворення в голоцені. оєдн ння клім тичних умов р ннього голоцену з поч тковою безк рбон тністю лесової товщі сприяли освоєнню території лісовою рослинністю (березово-соснові ліси). ослідження фосф тів гумусових горизонтів опідзолених чорноземів ьвівського пілля з свідчують, що орг нічні фосф ти люмінію і з ліз перев ж ють н д їхніми мінер льними форм ми [2]. е д є підст ву припустити, що опідзолені чорноземи пілля в своєму розвитку пройшли через ст дію опідзолення ще в р нньому голоцені. цій ст дії вони були, ймовірно, темноз $б$ рвленими сл бкоопідзоленими і текстурно-диференційов ними грунт ми.

осл блення дрен жу території у середньому голоцені т р птове потепління привели до сукцесійних змін у ст ні лісової рослинності т м сшт бного розширення релів дубових соці цій п ркового типу, більш конкурентних у нових ед фічних умов х. іброви і вл стивий їм дерновий тип грунтоутворення п нув ли ж до поч тку субтл нтичного періоду. цей ч с грунтоутворення увійшло в ст дію ктивної прогр д ції чорноземів. в ж ючи н $\mathrm{p}$ нньоголоценову ст дію опідзолення грунтів, н йімовірніше відбув ється прогр д ція чорноземів з темно-сірих лісових грунтів. езпосереднього підтвердження цьому нем є, проте $є$ нез перечні док зи того, що у чорноземи можуть еволюціонув ти лише темно-сірі лісові грунти. і ст дії більш диференційов ного й опідзоленого грунту прогр д ція чорноземів неможлив [8]. н слідок прогр д ції грунтотвірний процес супроводжується збільшенням вмісту гумусу з одноч сним н копиченням біогенного к льцію. ме в дібров х створюються сприятливі умови для н копичення гумусу і ввібр ного к льцію у верхньому гумусовому горизонті [9]. і грунти вже з опис них умов н був ють озн к, х р ктерних для опідзолених чорноземів.

уб тл нтичне похолод ння і збільшення зволоженості території ерхньодністерського і озтоцько- пільського лісових грунтово-бот нічних округів призвели до посилення їхнього з ліснення без зміни видового скл ду рослинних соці цій. кщо зв жити н те, що трив лість і м сшт би природного 3 ліснення були суттєво обмежені поч тком інтенсивного зведення лісів людиною (звідси історичн н зв пілля), екологічні умови дібров не сприяють інтенсивній дегр д ції мінер льної ч стини грунтів, то можн дійти висновку, що озн ки опідзолення н фоні текстурної диференці ції профілю суч сних чорноземів опідзолених личини зн чно реліктові (p нньоголоценові). теперішніх умов х трив лого господ рського використ ння чорноземів вони підтримув ні процес ми псевдооглеєння, лесив жу, брюніфік ції н фоні м сшт бного профільного оглеєння.

сторія розвитку рослинності і грунтового покриву личини, особливості будови профілю чорноземів свідч ть про можливість їхнього прогресивного розвитку в умов $\mathrm{x}$ лісового типу рослинності. сторичні зміни грунтоутворення зумовили розвив льний тип еволюції чорноземів опідзолених у голоцені. кий підхід до еволюції чорноземів повинен відобр зитись н їхньому кл сифік ційному положенні т уточненні грунтово- 
геогр фічного р йонув ння чорноземної зони кр їни. ілком зрозуміло, що продовження лісостепової зони кр їни в меж х 3 хідної ч стини личини є логічним ф ктом, побудов ним н помилкових уявленнях про генезу чорноземів цього кр ю. ст ннє фізико-геогр фічне р йонув ння кр їни ч стково ліквідув ло цей логізм. роте незміненими з лишились чинники, н підст ві яких л ндш фти ерхньодністерського і озтоцько- пільського регіонів личини віднесені до з хіднолісостепових: грунти, що 3 морфохром тичними озн к ми і вл стивостями гумусової ч стини профілю дуже подібні до чорноземів, т кож клім тичні умови.

1. лекс ндровский . . волюция почв осточной вропы н гр нице между лесом и степью // стественн я и нтропогенн я эволюция почв. ущино, 1988. . 82-94.

2. ндрущенко . . рунти з хідних обл стей . ьвів. убляни, 1970.185 с.

3. еобот нічне р йонув ння кр їнської : ук. думк , 1977. . 140-194.

4. ністрянський . . тнополітичн геогр фія кр їни: проблеми теорії, методології, пр ктики: оногр фія. ввів: ітопис, 2006. 490 с.

5. в лишин . . очвы узнецкой лесостепи // тери лы узнецко- рн ульской почвенной экспедиции. . .; ., 1931..3. . .21-201.

6. л ссифик ция почв оссии. .. очвенный институт им. . . окуч ев 2000. .130-135.

7. рупеников . . стория почвоведения (от времени его з рождения до н ших дней). .: ук, $1981.315 \mathrm{c}$.

8. рголин . ., лекс ндровский . ., льичев . . и др. озр ст и эволюция черноземов. ., 1988. $144 \mathrm{c}$

9. боких . . екоторые вопросы подзолообр зов ния // тери лы по исслед. почв и грунтов ерсонской губ. 1915. ып. 2.

10. отинский . . олоцен еверной вр зии. ., 1977. . 18-30.

\section{GENESIS PROBLEMS OF CHERNOZEMS OF THE GALICIA}

\section{Papish, S. Pozniak}

Ivan Franko National University of Lviv, . Doroshenko St., 41, UA - 79000 Lviv, Ukraine

The problems of genesis and classification of chernozems of Galicia is being considerated within the common theory of the evolution of chernozems of the forest-steppe zone of Ukraine. In the soilbotanical conditions of the West forest-steppe of Ukraine the character and trend direction of the last Holocene evolution of chernozems is diverse.

Key words: chernozems, pheozems, soil cover, Galicia, soil evolution, classification, soil horizon, morphological features. 


\section{. пиш, . озняк \\ ьвовский н ицон льный университет имени вн ул. . орошенко, 41, г. ьвов, 79000, кр ин}

ссмотрено проблемы генезис и кл ссифик ции черноземов лиции в русле общей теории эволюции черноземов лесостепной зоны кр ины. почвенно-бот нических условиях п дной есостепи кр ины х р ктер и н пр вление позднеголоценовой эволюции черноземов являются р знон пр вленными.

лючевые слов : черноземы, феоземы, почвенный покров, лиция, эволюция почв, кл ссифик ция, почвенный горизонт, морфологические призн ки.

т ття н дійшл до редколегії 26.05.2009 рийнят до друку 20.09.2009 